\title{
Determination of Antimicrobial and Antioxidant Activity of Alchemilla alpina L.
}

\author{
Şule İnci ${ }^{1, a, *}$, Ayşe Eren ${ }^{2, b}$, Sevda Kirbağ ${ }^{3, c}$ \\ ${ }^{1}$ Department of Biology, Science Faculty, Firat Üniversity, 23270 Elazlğ, Turkey \\ ${ }^{2}$ Department of Molecular Biyology and Genetics, Science Faculty, Dicle Üniversity, 21000 Diyarbakır, Turkey \\ ${ }^{3}$ Department of Biology, Science Faculty, Firat University, 23270 Elazı̆̆, Turkey
}

*Corresponding author

A R T I C L E I N F O A B S T R A C T

Research Article

Alchemilla genus, which belongs to the Rosaceae family, is a medicinal plant used for various purposes among the people. Species of this genus are known in Turkish folk medicine as lion claw or hazelnut grass. Especially, they are used mainly women's illnesses, in gastritis, antiinflammatory, as carminative, and in the treatment of wound. Besides the antimutagenic effect of

Received : 11/07/2021

Accepted : 05/09/2021 Alchemilla alpina L., its above-ground parts are used for antimycotic purposes in the form of tea or oral care water. In this study, it has been aimed to determine the antimicrobial effect of the aboveground parts of Alchemilla alpina extracts obtained from methanol, ethanol and chloroform and the antioxidant activity of different concentrations of the extract obtained from methanol. The antimicrobial activity of methanol, ethanol and chloroform extracts of the above-ground parts of $A$. alpina has been determined according to disk disc diffusion method. In the results obtained have

Keywords: Medicinal plant Alchemilla alpina Layd's-mantle Antimicrobial effect Antioxidant effect been showed that these extracts inhibited the growth of some bacteria (Staphylococcus aureus ATCC25923, Escherichia coli ATCC25322, Klebsiella pneumoniae ATCC700603, Bacillus megaterium DSM32) and yeasts (Candida albicans FMC17 and Candida glabrata ATCC66032) at different rates $(8-23 \mathrm{~mm})$. The antioxidant activity of different concentrations $(1.25,2.5,5$ and 10 $\mathrm{mg} / \mathrm{ml}$ ) of the above-ground parts of $A$. alpina extract obtained from methanol has been determined according to the 2,2-diphenyl-1-picrylhydrazyl (DPPH) radical scavenging capacity method. In the results obtained, it has been observed that the effect of removing DPPH radical of A. alpina increased depending on increasing concentrations.

\section{Introduction}

Medicines from natural products have been used in folk medicine for centuries. Because they are known to have fewer side effects than synthetic drugs (Banerjee et al., 2018). Especially in recent years, due to the increase in the side effects of the drugs used in treatment, patients are turning to herbal products that are more natural and have less risk in terms of side effects (Ege and Elmastaş, 2020). The use of plants in folk medicine based back much earlier than modern medicine. According to the World Health Organization, $80 \%$ of the world's population still relies on plant-based medicines. (Uritu et al., 2018).

It is a medicinal plant belonging to the genus Alchemilla L. Rosaceae, especially known as lion paw or nut grass in our country (Ozbek et al., 2017; Acet and Özcan, 2018). It is known that these species have many biological effects such as antioxidant, antimicrobial, diuretic, tonic, reproductive disorders, cell regenerative and antidiabetic and they are used in many regions for this purpose (Viegi et al., 2003; Altundag and Öztürk, 2011; Kaya and Artuvan, 2016; Ozbek et al., 2017). Especially, they are used mainly women's illnesses, in gastritis, antiinflammatory, as carminative, and in the treatment of wound. Besides the antimutagenic effect of Alchemilla alpina L., its above-ground parts are used for antimycotic purposes in the form of tea or oral care water.

In this study, it has been aimed to determine the antimicrobial effect of the above-ground parts of Alchemilla alpina extracts obtained from methanol, ethanol and chloroform and the antioxidant activity of different concentrations of the extract obtained from methanol. 


\section{Materials and Methods}

\section{Obtaining and Preparation of Plant Material}

A. alpina was purchased commercially from a local herbalist in 2020. The plant material was pulverized. 0.5 grams of sample was taken. Each sample was kept in an orbital shaker at $100 \mathrm{rpm}$ for 72 hours to obtain an extract using $100 \mathrm{ml} \mathrm{96 \%} \mathrm{methanol,} \mathrm{ethanol} \mathrm{and} \mathrm{chloroform}$ solvents. It was then filtered using Whatman filter paper.

\section{Determination of Antimicrobial Effect}

\section{Test microorganisms}

In this study; Staphylococcus aureus ATCC25923, Escherichia coli ATCC25322, Klebsiella pneumoniae ATCC 700603, Bacillus megaterium DSM32, Salmonella thypii ve Candida albicans FMC17 microorganisms were used. Microorganism cultures were obtained from Firat University, Faculty of Science, Department of Biology, Microbiology Laboratory culture collection.

Preparation of microorganism cultures and testing for antimicrobial

The antimicrobial activity of extracts of A. alpina obtained from ethanol, chloroform and methanol solvents were determined according to the disc diffusion method (Collins and Lyne, 2004). Bacteria strains (Staphylococcus aureus ATCC25923, Escherichia coli ATCC25322, Klebsiella pneumoniae ATCC 700603, Bacillus megaterium DSM32, Salmonella thypii) were inoculated into Nutrient Broth (Difco) for 24 hours at $35 \pm 1^{\circ} \mathrm{C}$ and yeast strains (Candida albicans FMC17) were incubated in Malt Extract Broth (Difco) for 48 hours at $25 \pm 1{ }^{\circ} \mathrm{C}$. The culture of the prepared bacteria and yeast broth, respectively; was inoculated into Müeller Hinton Agar and Sabouraud Dextrose Agar at a rate of $1 \%\left(10^{6}\right.$ bacteria $/ \mathrm{ml}$, $10^{4}$ yeast $/ \mathrm{ml}$ ). Then, after shaking well, $25 \mathrm{ml}$ was placed in sterile petri dishes of $9 \mathrm{~cm}$ diameter. A homogeneous distribution of the medium was achieved. $6 \mathrm{~mm}$ diameter antimicrobial discs (Oxoid), each impregnated with extracts of $100 \mu \mathrm{l}(500 \mu \mathrm{g})$ were lightly placed on the solidified agar medium. After the petri dishes prepared in this way were kept at $4^{\circ} \mathrm{C}$ for $1.5-2$ hours, the plates inoculated with bacteria were incubated at $37 \pm 0.1^{\circ} \mathrm{C}$ for 24 hours, and the plates inoculated with yeast at $25 \pm 0.1^{\circ} \mathrm{C}$ for 72 hours. As controls, different standard discs were used for bacteria (Streptomycin sulphate $10 \mu \mathrm{g} / \mathrm{disc}$ ) and yeasts (Nystatin $30 \mu \mathrm{g} /$ disc). Dimethyl sulfoxide (DMSO) was used for negative control. Zones of inhibition were measured in $\mathrm{mm}$.

\section{Determination of Antioxidant Effect}

Antioxidant activity was determined by the free radical scavenging activity of 2,2-diphenyl-1-picrylhydrazyl (DPPH) (Sharma and Bhat, 2009; Dimitrova et al., 2010). DPPH solution was prepared to be $0.004 \%$ in methanol. Serial concentrations $(1.25,2.5,5,10 \mathrm{mg} / \mathrm{ml})$ of plant extracts were prepared by dissolving in methanol. $30 \mu \mathrm{l}$ of plant extract was added on $3 \mathrm{ml}$ of DPPH solution. It was left in the dark for 30 minutes at room temperature. Then, reading was done at $517 \mathrm{~nm}$ in the spectrophotometer. The antioxidant activity was repeated three times. Butylated hydroxyanisole (BHA) and methanol were used as controls. The antioxidant activity was calculated by the formula below:
DPPH inhibition $(\%)=\frac{(\text { AbsControl-AbsSample })}{\text { AbsControl }} \times 100$

AbsControl $=$ Absorbance of DPPH-methanol solution, AbsSample $=$ Absorbance of plant extract.

\section{Statistical Analysis}

The statistical analysis of the study was made according to the kruskal wallis test.

\section{Results and Discussion}

\section{Antimicrobial Effect}

Natural remedies are used in the treatment of diseases in many developing countries. In this sense, plants are natural products that are beneficial for human health in the fight against infections (Onbaşlı et al., 2020). For this purpose, the antimicrobial effect of different extracts of $A$. alpina was determined in this study.

The antimicrobial effects of methanol, ethanol and chloroform extracts of A. alpina against the microorganisms used are shown in Table 1.

The antimicrobial effects of methanol, ethanol and chloroform extracts of A. alpina against E. coli were determined as $18 \mathrm{~mm}, 15 \mathrm{~mm}$ and $8 \mathrm{~mm}$, respectively (Table 1). While the methanol and ethanol extracts of A. alpina formed an inhibition zone (20-15mm) against $K$. pneumoniae at different rates, chloroform extract did not create an inhibition zone (Table 1). It was been determined that A. alpina extracts obtained from different solvents show antimicrobial effect against $C$. albicans at different rates $(22-10 \mathrm{~mm})$ (Table 1$)$. The ethanol extract of $A$. alpina showed the highest antimicrobial effect $(20 \mathrm{~mm})$ against $C$. glabrata (Table 1). While methanol $(23 \mathrm{~mm})$ and ethanol (15mm) extracts of $A$. alpina showed antimicrobial activity against $S$. aureus, chloroform extract did not show antimicrobial activity (Table 1). A. alpina extracts obtained from methanol, ethanol and chloroform solvents formed $20 \mathrm{~mm}, 15 \mathrm{~mm}$ and $8 \mathrm{~mm}$ inhibition zones against $B$. megaterium, respectively (Table 1 ).

In previous studies, Alchemilla ellenbergiana Rothm. ethanol extract showed an $18 \mathrm{~mm}$ inhibition zone against Candida albicans, and ethyl acetate and methanol extracts showed $13 \mathrm{~mm}$ and $12 \mathrm{~mm}$ inhibition against methicillin resistant S. aureus (MRSA), respectively. Against $K$. pneumoniaea, ethanol and ethyl acetate extracts showed an equal inhibition zone of $11 \mathrm{~mm}$ (Acet and Özcan, 2018). It was determined that Alchemilla glabra Neygenf showed antimicrobial activity at different rates $(12-22 \mathrm{~mm})$ against some strains of $E$. coli and $S$. aureus. In the same study, it formed $22-17 \mathrm{~mm}$ inhibition zone against $P$. vulgaris at different concentrations, $14-16 \mathrm{~mm}$ inhibition zone against C. albicans and $13-15 \mathrm{~mm}$ inhibition zone against $K$. pneumoniae (Denev et al., 2014). Alchemilla vulgaris L. extracts showed an inhibition rate of $86.98 \%$ against Phytopthora infestans and $81.57 \%$ against Macrophamina phaseolina, $63.11 \%$ against Alternaria alternata and $45.20 \%$ against Cylindrocarpon destructans. (Özbek et al., 2021). In Australia and Iceland, ethanol extract from the aerial parts of A. alpina and petroleum ether extracts of the roots of $A$. faeroensis and A. vulgaris plants were found to be active against Plasmodium falciparum. (İlgün et al., 
2014). It was determined that the extracts of $A$. mollis in different solvents showed antimicrobial activity at different rates against Staphylococcus aureus, Escherichia coli, Pseudomonas aeruginosa, Enterococcus faecalis and Klebsiella pneumoniae microorganisms, but did not prevent the development of Candida albicans (Kaya et al., 2009). The inhibition zones of the methanol extract of Alchemilla molis (Buser) Rothm. against E. coli, S. typhimurium, $S$. aures, $S$. enteriditis and $C$. albicans were reported as $12.16 \pm 1.04,10 \pm 1,18.66 \pm 0.57,22 \pm 1$ and $15 \pm 1$ mm, respectively. (Şeker Karatoprak et al., 2017). A. acutifolius and $A$. officinalis were found to be effective at $50-400 \mu \mathrm{g} / \mathrm{mL}$ concentrations against Staphylococcus aureus, Enterococcus faecalis, Escherichia coli, Pseudomonas aeruginosa, Acinetobacter baumannii, Candida albicans, Candida krusei and Candida glabrata. (Mohammed et al., 2021a). The minimum inhibitory concentrations of the methanol, ethanol and dichloromethane extract of $S$. marianum against $S$. aureus, S. aureus MRSA, E. coli, P. aeruginosa, C. glabrata, $C$. albicans are calculated between 25-800 $\mu \mathrm{g} / \mathrm{mL}$ (Mohammed et al., 2019). The minimum inhibitory concentration values of $M$. longifolia subsp longifolia collected from different localities were determined between $50 \mu \mathrm{g} / \mathrm{mL}$ and $800 \mu \mathrm{g} / \mathrm{mL}$ against some microorganisms (S. aureus, E. faecalis, E. coli, $P$. aeruginosa, C. albicans, C.tropicalis) (Sevindik et al., 2017). In the results obtained, it is seen that when the antimicrobial effect of $A$. alpina against pathogenic microorganisms is compared with similar species and different plant species, the results show differences. Because the antimicrobial effect varies depending on the microorganisms used, the solvent, the plant species used and their habitats.

Table 1. Antimicrobial effect of ethanol methanol and chloroform extracts of A. alpina (mm)

\begin{tabular}{l|cccccc}
\hline & E. coli & K. pneumoniae & C. albicans & C. glabrata & S.aureus & B. megaterium \\
\hline A. alpina-M & 18 & 20 & 20 & 18 & 23 & 20 \\
A. alpina $-\mathrm{E}$ & 15 & 15 & 22 & 20 & 15 & 15 \\
A. alpina -C & 8 & - & 10 & 11 & - & 8 \\
\hline Control & 11 & 18 & 10 & 23 & 15 & 10 \\
\hline
\end{tabular}

A. alpina-M: Methanol extract of A. alpina; A. alpina-E: Ethanol extract of A. alpina; A. alpina-C: Chloroform extract of A. alpina

Table 2. Percent inhibition of the DPPH radical of A. alpina

\begin{tabular}{l|c}
\hline \multicolumn{1}{c|}{ Concentrations } & Percent inhibition \\
\hline BHA & $84.5 \pm 0.257$ \\
MetOH & $1.5 \pm 0.724$ \\
$1.25 \mathrm{mg} / \mathrm{ml}$ & $45.4 \pm 0.440$ \\
$2.5 \mathrm{mg} / \mathrm{ml}$ & $67.8 \pm 0.978$ \\
$5 \mathrm{mg} / \mathrm{ml}$ & $84.8 \pm 1.348$ \\
$10 \mathrm{mg} / \mathrm{ml}$ & $94.4 \pm 1.301$ \\
\hline
\end{tabular}

\section{Antioxidant Effect}

Antioxidants are compounds that can eliminate the harmful effects of free radicals. For this reason, in order to minimize the harmful effects of synthetic antioxidants used today, the tendency towards natural antioxidants is increasing (Çelik and Ayran, 2020). Especially for this purpose, researches on the natural antioxidant capacities of plants are increasing. Therefore, in this study, the antioxidant effect of the aerial parts of A. alpina was determined.

The results of the DPPH radical scavenging effect of different concentrations of the methanol extract of the aerial parts of $A$. alpina are shown in Table 2 .

The percentage of inhibition of the DPPH radical scavenging effect of the methanol extract of A. alpina was found to be in the range of $45.4 \pm 0.440-94.4 \pm 1.301 \%$, depending on the varying concentrations (Table 2).

In one study, it was determined that the antioxidant effects of water and methanol extracts of Alchemilla molis Buser were increased up to a certain point, but still low (Uçar Sözmen et al., 2020). The highest DPPH radical scavenging effect of Alchemilla ellenbergiana Rothm. was found in the ethanol extract $(243.6 \mu \mathrm{g} / \mathrm{ml})$, and the methanol extract $(243.1 \mu \mathrm{g} / \mathrm{ml})$ was found to be very close. The lowest DPPH radical scavenging activity was also determined in the hexane extract $(7.1 \mu \mathrm{g} / \mathrm{ml}$ ) (Acet and Ozcan, 2018). It was reported that the antioxidant activities of methanol extracts of Alchemilla species were high. (Usta et al., 2013). The antioxidant effect of Alchemilla glabra was determined using various methods. In the results obtained, ORAC, TRAP and HORAC were calculated as $1337 \pm 68 \mu \mathrm{mol} \mathrm{TE} / \mathrm{g}, 1815 \pm 38 \mu \mathrm{mol} \mathrm{TE} / \mathrm{g}$, and $1999 \pm 70$ $\mu \mathrm{mol} \mathrm{GAE} / \mathrm{g}$, respectively (Denev et al., 2014). It was determined that Allcemilla sericata Rchb. was $58.9 \%$ scavenging effect on DPPH radical and Iron(III) ion reducing antioxidant power (FRAP) was $770.8 \mu \mathrm{mol} F$ II/g (Murathan, 2018). The IC50 values of the DPPH radical scavenging effect of $70 \%$ methanol and water extract of Alchemilla molis were calculated as $0.21 \pm 0.001$ $\mathrm{mg} / \mathrm{ml}$ and $0.24 \pm 0.002 \mathrm{mg} / \mathrm{ml}$, respectively (Şeker Karatoprak et al., 2017). The percentage inhibition of the DPPH radical scavenging effect of the leaf extract of Alchemilla vulgaris (L.) was reported as $71.8 \pm 4.1 \%$ (Oktyabrsky et al., 2009). The TAS value of the ethanol extract obtained from the flower parts of Datura stramonium was determined as $7.559 \pm 0.224 \mathrm{mmol} / \mathrm{L}$ and the TOS value was determined as $10.711 \pm 0.243 \mu \mathrm{mol} / \mathrm{L}$ (Mohammed et al., 2021b). It has been reported that the antioxidant effect of different concentrations of $M$. longifolia subsp. longifolia is between $92.94 \pm 1.83 \%$ and $48.46 \pm 1.32 \%$. TAS values of ethanol extract of $M$. longifolia subsp. longifolia collected from different localities were determined in the $1.809 \pm 0.07-3.628 \pm$ $0.234 \mathrm{mmol} / \mathrm{L}$ range and TOS values of the same species 
were detected in the $11.058 \pm 0.610-14.077 \pm 0.634$ range $\mu \mathrm{mol} / \mathrm{L}$ (Sevindik et al., 2017). TAS values of $A$. acutifolius and A. officinalis were reported to be $6.238 \pm$ 0.032 and $7.449 \pm 0.088$, respectively, and TOS values were reported to be as $13.892 \pm 0.162$ and $18.607 \pm 0.352$, respectively (Mohammed et al., 2021). The TAS value of the ethanol extract of Thymbra spicata L. was $8.399 \pm 0.102$ and the TOS value was $6.530 \pm 0.115$. (Mohammed et al., 2020). TAS and TOS values of ethanol extract of Rosa canina were determined as $4.602 \pm 0.215 \mathrm{mmol} / \mathrm{L}$ and $6.294 \pm 0.191 \mu \mathrm{mol} / \mathrm{L}$ (Pehlivan et al., 2018). When the results were compared with the results in the literature, it was determined that the antioxidant effect of A. alpina was higher at $10 \mathrm{mg} / \mathrm{ml}$.

Generally, sometimes the variability of the results may vary depending on the harvest time of the plant, ecological conditions, plant species, concentration and solvents used.

\section{Conclusion}

In this study, antimicrobial effect and antioxidant effect of A. alpina against some microorganisms were determined. It was determined that the methanol extract of A. alpina showed the best antimicrobial effect against $S$. aureus. In addition, it was determined that methanol extract had the highest antioxidant activity at $10 \mathrm{mg} / \mathrm{ml}$. The fact that the biological effects of Alchemilla species are low in the literature and that A. alpina is not included in the studies makes this study important. This study the results obtained will contribute to the literature and that the biological effects of A. alpina may be important.

\section{Acknowledgements}

Data of the study is presented ans the study is placed in 4th International Conference on Physical Chemistry and Functional Materials Congress Abstract book (08-09 April 2021, pp. 40)

\section{References}

Acet T, Kadriye Özcan K. 2018. Determination Of antioxidant and antimicrobial properties of lady's mantle (Alchemilla ellenbergiana) extracts. Gümüşhane Üniversitesi Fen Bilimleri Enstitüsü Dergisi, 8 (1): 113-121. do1: 10.17714/gumusfenbil.308430

Altundag E, Ozturk M. 2011. Ethnomedicinal studies on the plant resources of East Anatolia, Turkey, Procedia Social and Behavioral Sciences, 19: 756-777. doi: Http://Dx.Doi.Org/10.1016/J.Sbspro.2011.05.195

Banerjee J, Das A, Sinha M, Saha S. 2018. Biological efficacy of medicinal plant extracts in preventing oxidative damage. Oxidative Medicine and Cellular Longevity, 2018: 2. doi: https://doi.org/10.1155/2018/7904349

Çelik A, Ayran İ. 2020. Antioksidan kaynağı olarak bazı tıbbi ve aromatik bitkiler. Türk Bilimsel Derlemeler Dergisi, 13(2): $115-125$.

Davis, P. H. (1972). Flora of Turkey and the Aegean Islands. V:4 Edinburgh Univ. Press. England.

Denev P, Kratchanova M, Ciz M, Lojek A, Vasicek O, Blazheva D, Nedelcheva P, Vojtek L, Hyrsl P. 2014. Antioxidant, antimicrobial and neutrophil-modulating activities of herb extracts. Acta Biochimica Plonica, 61, 359-367. doi: 10.18388/abp.2014_1907

Dimitrova DZ, Nedialkov P, Kitanov G. 2010. Radical scavenging and antioxidant activities of methanolic extracts from Hypericum species growing in Bulgaria. Pharmacognosy Magazine, 6, 74-78. doi: 10.4103/09731296.62889 .
Ege M, Elmastaş M. 2020. Antiviral etkili fitoterapötikler: tıbbi bitkiler ve fitokimyasallar. Journal Of Integrative And Anatolian Medicine, 1(2): 5-20.

Collins CM, Lyne PM. 2004. Microbiological methods. In: Collins CH, Lyne PM, Grange JM, Flkinham III JO, editors. Mycological methods. 8 ed. London, p. 140. ISBN 0-34080896-9

İlgün S, Baldemir A, Koşar M. 2014. Alchemilla L. türlerinin kimyasal bileșikleri ve biyolojik aktiviteleri. Hacettepe University Journal of the Faculty of Pharmacy, 34, 17-30.

Kaya E, Şeker Karatoprak G, Koşar M, Özbilge H, Başer KHC. 2009. Antimicrobial Properties Of Alchemilla mollis, Ankara, Türkiye, 23 June- 26 September 2009, 9th International Symposium On Pharmaceutical Sciences (ISOPS-9).

Kaya B, Artuvan Y. 2016. Investigation of antioxidant and antimicrobial effect, phenolic compounds of Alchemilla cimilensis. El-Cezerî Journal Of Science And Engineering, 3(1), 27-54.

Şeker Karatoprak G, İlgün S, Koşar M. 2017. Phenolic composition, anti-inflammatory, antioxidant, and antimicrobial activities of Alchemilla mollis (Buser) Rothm. Chemistry \& Biodiversity, 14 (9): e1700150. doi: https://doi.org/10.1002/cbdv.201700150

Mohammed FS, Pehlivan M, Sevindik M. 2019. Antioxidant, antibacterial and antifungal activities of different extracts of Silybum marianum collected from Duhok (Iraq). International Journal of Secondary Metabolite, 6(4): 317-322.

Mohammed FS, Şabik AE, Sevindik E, Pehlivan M, Sevindik, M. 2020. Determination of Antioxidant and Oxidant Potentials of Thymbra spicata Collected from Duhok-Iraq. Turkish Journal of Agriculture-Food Science and Technology, 8(5): 1171-1173. DOI: 10.24925/turjaf.v8i5.1171-1173.3341

Mohammed FS, Kına E, Sevindik M, Dogan M, Pehlivan M. 2021b. Datura stramonium (Solanaceae): Antioxidant And Antimicrobial Potentials. Turkish Journal Of Agriculture Food Science And Technology, 9(4): 818-821. DOI: https://doi.org/10.24925/turjaf.v9i4.818-821.4264

Mohammed FS, Pehlivan M, Sevindik E, Akgul H, Sevindik M, Bozgeyik I, Yumrutas O. 2021a. Pharmacological properties of edible Asparagus acutifolius and Asparagus officinalis collected from North Iraq and Turkey (Hatay). Acta Alimentaria, 50(1): 136-143. doi: https://doi.org/10.1556/066.2020.00204

Murathan ZT. 2018. Kuzeydoğu anadolu bölgesi ekolojik koşullarında yetişen bazı tıbbi bitkilerin biyokimyasal içeriğ ve antioksidan özelliklerinin belirlenmesi. Balıkesir Üniversitesi Fen Bilimleri Enstitüsü Dergisi, 20(2): 51-60. doi: 10.25092/baunfbed.468493

Oktyabrsky O, Vysochina G, Muzyka N, Samoilova Z, Kukushkina T, G. Smirnova G. 2009. Assessment of antioxidant activity of plant extracts using microbial test systems. Journal Of Applied Microbiology, 106: 1175-1183. Doi: https://doi.org/10.1111/j.1365-2672.2008.04083.x

Onbaşlı D, Yuvalı Çelik G, Türk Katırcıoğlu H. 2020. İlaca dirençli mikroorganizmalara karşı yeni bir yaklaşım: geleceğin antibiyotikleri, bitkisel antimikrobiyal peptidler. Erciyes Üniversitesi Sağlık Bilimleri Fakültesi Dergisi, 7(1): 51-57.

Ozbek H, Acikara OB, Keskin I, Kirmizi NI, Ozbilgin S, Ergene Oz BE, Kurtul E, Ozrenk BC, Tekine M, Saltan G. 2017. Evaluation Of Hepatoprotective And Antidiabetic Activity Of Alchemilla mollis. Biomedicine \& Pharmacotherapy, 86: 172-176. doi: https://Doi.Org/10.1016/J.Biopha.2016.12.005

Özbek O, Budak Y, Özyiğit Ç, Yanar Y. 2021. Bitki patojeni funguslara karş1 Grindelia robusta Nutt., Tanacetum praeteritum Subsp. praeteritum ve Alchemilla vulgaris L. ekstraktlarının antifungal aktivitelerinin değerlendirilmesi. Turkish Journal of Science and Health, 2(1): 57-6.

Pehlivan M, Mohammed FS, Sevindik M, Akgul H. 2018. Antioxidant and oxidant potential of Rosa canina. Eurasian Journal of Forest Science, 6(4): 22-25. 
Sharma OP, Bhat TK. 2009. DPPH antioxidant assay revisited. Food Chemistry, 113: 1202-1205. doi:10.1016/ J.Foodchem.2008.08.008Get

Şeker Karatoprak G, İlgün S, Koşar M. 2017. Phenolic composition, anti-1nflammatory, antioxidant, and antimicrobial activities of Alchemilla mollis (Buser) Rothm. Chemistry \& Biodiversity, 14 (9): e1700150. doi: https://doi.org/10.1002/cbdv.201700150

Sevindik M, Akgul H, Pehlivan M, Selamoglu Z. 2017. Determination of therapeutic potential of Mentha longifolia ssp. longifolia. Fresen Environ Bull, 26(7): 4757-4763.

The Plant List 2021. Publish On The İnternet. Available from: http://www.theplantlist.org/tp11.1/record/kew-2523483 [Accessed April 2021]
Uçar Sözmen E, Eruygur N, Akpulat Ha, Çetın Md, Durukan H, Demırbaş A, Karaköy T. 2020. Sivas ili doğal florasından toplanan sarı kantaron (Hypericum scabrum L.) ve aslan pençesi (Alchemilla mollis (Buser) Rothm.) bitkilerinin bazı kalite kriterlerinin belirlenmesi. Iğdır Üniversitesi Fen Bilimleri Enstitüsü Dergisi, 10(2): 1410-1418. doi: 10.21597/jist.655128

Uritu CM, Mihai CT, Stanciu GD, Dodi G, Alexa-Stratulat T, Luca A, Leon-Constantin MM, Stefanescu R, Bild V, Melnic S, Tamba BI. 2018. Medicinal plants of the family Lamiaceae in pain therapy: a review. Pain Research and Management, 2018: 44. doi: https://doi.org/10.1155/2018/7801543

Usta C, Yildirim AB, Turker AU. 2014. Antibacterial and antitumour activities of some plants grown in Turkey. Biotechnology \& Biotechnological Equipment, 28(2), 306315. doi: 10.1080/13102818.2014.909708

Viegi L, Pieroni A, Guarrera PM, Vangelisti R. 2003. A review of plants used in folk veterinary medicine in Italy as basis for a databank. Journal Of Ethnopharmacology, 89(2-3), 221244. doi: https://doi.org/10.1016/j.jep.2003.08.003 